ESJ Natural/Life/Medical Sciences

\title{
Length-Weight Relationship And Condition Factor Of Mangrove Fish Species In Azagny National Park (Grand- Lahou Department, Ivory Coast)
}

\author{
Kouadio Kouassi Alain,
}

Doctoral student at the laboratory of Natural Environments and Biodiversity Conservation, Faculty of Biosciences, Félix Houphouët-Boigny University, Ivory Coast, Ivorian,

\section{Yao Stanislas Silvain,}

Senior Lecturer at the Laboratory of Natural Environments and Biodiversity Conservation, Faculty of Biosciences, Félix Houphouët-Boigny University, Ivory Coast

\section{Kamelan Tanoh Marius,} Konan Yao Aristide,

Assistant Professor, Laboratory of Natural Environments and Biodiversity Conservation, UFR Faculty of Biosciences, Félix Houphouët-Boigny

University, Ivory Coast

\section{Doi:10.19044/esj.2022.v18n8p158}

Submitted: 08 November 2021

Accepted: 28 January 2022

Published: 28 February 2022
Copyright 2022 Author(s)

Under Creative Commons BY-NC-ND 4.0 OPEN ACCESS

Cite As:

Alain K.K., Silvain Y.S.,Marius K.T., \& Aristide K.Y.,(2022). Length-Weight Relationship And Condition Factor Of Mangrove Fish Species In Azagny National Park (Grand-Lahou Department, Ivory Coast) European Scientific Journal, ESJ, 18 (8), 158. https://doi.org/10.19044/esj.2022.v18n8p158

\section{Abstract}

The length-weight relationship and condition factor of mangrove fish species in Azagny National Park (ANP) were studied, to provide baseline data of the impact of mangrove disturbances on ichthyofauna. Specimens were captured from March 2019 to February 2020 using gillnets and mesh traps. After identification, each specimen was weighed to the nearest gram and measured to the nearest millimeter. Twenty-eight species belonging to 17 families and 24 genera were selected based on their numbers (only species with at least 10 specimens were considered). Most of these species have a negative allometry (22 species, 78.57\%). 14.28\% species showed positive allometry and $7.14 \%$ species showed isometry. The length-weight regressions 
are significant with a coefficient of determination $\left(\mathrm{r}^{2}\right)$ varying between 0.115 for Chrysichthys maurus and 0.936 for Labeo coubie. The coefficient of allometry b varies from 0.413 for Chrysichthys maurus to 4.272 for Labeo coubie with a mean value of $2.384 \pm 0.810$. The condition factor ranged on average from $0.935 \pm 0.966$ for Schilbe mandibularis $113.3 \pm 10.644$ for Chrysichthys maurus. This study provides information on the effects of mangrove disturbance on the growth of species of the said ecosystem and contributes to the management of the ichthyofauna of the ANP.

Keywords: Length-Weight Relationship, Condition Factor, Mangroves, Azagny National Park, Grand-Lahou Department.

\section{Introduction}

Mangroves are one of the most productive ecosystems in the world and provide highly diverse ecosystem services (Barbier et al., 2011; UNEP, 2014). Duarte et al. (2020) estimate that these ecosystem services are all highly dependent on the ecological condition of the forest massifs. Indeed, mangroves offer a multitude of environments conducive to the feeding and development of fish, crustaceans and mollusks for which it is a breeding ground. It is the basis for the productivity of marine waters, and the back mangrove has good potential for aquaculture in brackish waters (Youmbi et al., 1991). On the other hand, mangroves are not immune to stresses related to global change, including first and foremost the risk of sea level rise, which may constitute a major threat locally (Gilman et al., 2008; Giri et al., 2011). In Ivory Coast, mangroves are increasingly degraded by their conversion into agricultural land, inhabited areas and infrastructure on the one hand and on the other hand by the various pressures and pollution they are subjected to (Égnankou, 2009 source). For example, Égnankou (2009) announced the considerable decrease of the surface area of the mangrove, between 1980 and 2005, from 30,200 ha to 9,900 ha in Ivory Coast. The mangroves of the ANP are not spared by this situation, whereas they contain a strong biological diversity. This plague impacts aquatic communities in general and the fish fauna in particular. The protection of these environments today is needed and it goes through good systematic, biological and ecological knowledge of the beings that live there (Lalèyé, 2006).

However, there are almost no studies that effectively and specifically address the ichthyofauna of the mangroves of the ANP. The aim of this study is to propose a rational management plan for fish stocks. It is based on the length-weight relationship and the condition factor. According to Hossain et al. (2012) and Bolognini et al. (2013), the length-weight relationship is an important tool in biology, physiology, ecology and stock assessment for the management and conservation of natural fish populations. Indeed, it is a 
critically important key used in fisheries assessment and in fish biology (Da Costa and Araàjo, 2003). The condition factor provides information on the overweight status of a fish (Lévêque et al., 1990). It is an instrument often used to compare the overall physiological status of populations over a seasonal cycle or between ponds with similar or different ecological conditions (Le Cren, 1951).

For Baby (2011), the condition factor can be used as an index to assess the level of disturbance in an aquatic ecosystem that is strongly influenced by environmental parameters. The present study aims to determine some biological knowledge base of the ichthyological fauna of the ANP mangroves and the effect of mangrove disturbance on the growth and condition of 28 fish species for appropriate management of the said ecosystem. It was done based on length-weight relationships and condition factor of fish.

\section{Materials And Methods \\ Study Area}

The study was conducted in the Azagny National Park (ANP) to Grand-Lahou in southwestern Ivory Coast, between $5^{\circ} 14^{\prime}$ and $5^{\circ} 31^{\prime}$ North and $4^{\circ} 76^{\prime}$ and $5^{\circ} 01^{\prime}$ West (Figure 1 ). ANP has an area of 19,400 ha with grassy savanna and dense forest vegetation (Avenard et al., 1971; Bouichou, 1978). Three quarters of the park's area is made up of the Bandama River-Ebrié Lagoon complex. According to Roth (1979), 45\% of its area is flooded throughout the year and $62 \%$ during the rainy seasons. This water regime gives the park an ecological specificity. Sampling was conducted at three stations along the study area. The stations were selected based on easy accessibility and the possibility of conducting a year-round sampling program.

\section{Fish Sampling}

Fish sampling campaigns were conducted monthly over a 12-month period from March 2019 to February 2020 using monofilament gillnets with mesh sizes between 10 and $35 \mathrm{~mm}$ and mesh pots with mesh sizes between 15 and $25 \mathrm{~mm}$. The duration of each campaign is 10 days. The gillnets were set at 5:00 p.m. and visited the next day at 7:00 a.m. for night fishing, and then lifted at 12:00 p.m. for day fishing. As far as the grid traps are concerned, they were set up in the evening around $5 \mathrm{pm}$ and collected the next day starting at $7 \mathrm{am}$. The specimens collected were identified using the identification keys of Paugy et al (2003a and b). Each individual captured was weighed using a TERRAILLON type electronic scale with a precision of $0.01 \mathrm{~g}$ and measured (SL) to the nearest $\mathrm{cm}$ using an ichthyometer. 


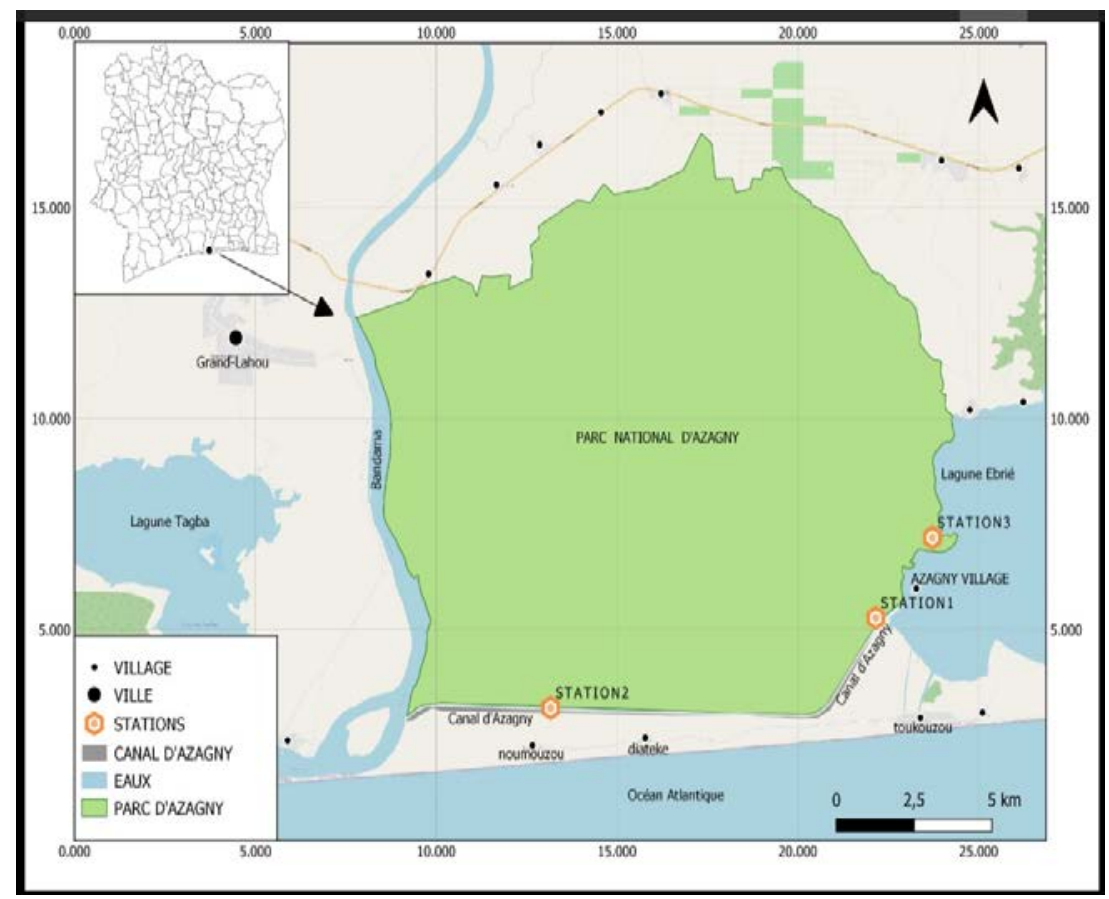

Figure 1: Location of sampling sites in Azagny National Park

\section{Data processing and statistical analysis}

To characterize the community structure of fishes in the study area, lengthweight relationships were established for fish species according to the formula of Le Cren (1951):

$$
\mathrm{Pt}=\mathrm{aSL} \mathrm{b}
$$

With Pt $=$ total mass of the fish in (g), SL = standard length of the fish in centimeter $(\mathrm{cm})$,

$\mathrm{a}=$ constant and $\mathrm{b}=$ allometry coefficient.

The parameters $a$ and $b$ were estimated after transforming the previous linear function into a logarithmic function of the formula:

$$
\log \mathrm{Pt}=\log \mathrm{a}+\mathrm{b} \log \mathrm{SL}
$$

In order to check whether the value of $b$ is significantly different from 3 , the Student's t-test was used $(p=0.05)$. The allometry coefficient $b$ varies between 2 and 4 but is most often close to 3 . When $b=3$, there is growth isometry (the growth in weight of the animal is equal to its growth in length). A coefficient $b$ greater than 3 indicates a better growth of the species in weight than in length (positive allometry) and, conversely, a better growth in length than in weight when $b$ is lower than 3 (negative allometry). The coefficient of determination $\left(r^{2}\right)$ was used as an indicator of the degree of correlation between length and mass.

For the present study, the Fulton condition factor (Bagenal, 1978) was calculated for each fish using the formula: 


$$
K=100 \mathrm{Pt} / S L^{3}
$$

With $\mathrm{Pt}=$ total fresh weight of the fish in $\mathrm{g}$.

$\mathrm{SL}=$ standard length of fish in centimeter.

3 = exponent of the weight-length relationship or allometry coefficient (b).

In the present study, only species represented by at least 10 specimens

(Batiabo et al., 2019; Ibala Zamba et al., 2020), from which presence was noted at all stations during the entire collection period were used.

\section{Results}

The length-weight relationship of 28 fish species studied are presented in Table I. A total of 2294 specimens belonging to 17 families were analyzed. The number of specimens vary from 10 (Pellonula vorax) to 658 (Sarotherodon melanotheron). The standard lengths (SL) of the specimens vary from $2.5 \mathrm{~cm}$ in Pellonula vorax to $50 \mathrm{~m}$ in Sarotherodon melanotheron with weights that vary between $1 \mathrm{~g}$ in Pellonula leonensis and Pellonula vorax and $1000 \mathrm{~g}$ in Neochelon falcipinnis. The coefficients of determination $\left(\mathrm{r}^{2}\right)$ of the linear regressions are ranged between 0.115 for Chrysichthys maurus and 0.936 for Labeo coubie and all regressions indicate a significant relationship $(\mathrm{p}<0.05)$ between length and weight of the fish studied. Furthermore, the values of $\left(\mathrm{r}^{2}\right)$ are greater than 0.90 for 4 species (14.28\%), 0.80 for 5 species (17.85\%) and less than 0.80 for 19 species (67.85\%).

The allometry coefficients (b) range from 0.413 for Chrysichthys maurus to 4.272 for Labeo coubie. The distribution of the allometry coefficient (b) for the 28 species studied has a mean value of $2.384 \pm 0.810$ (Figure 2).

In terms of growth, the allometry coefficient (b) of two species, Distichodus rostratus and Hepsetus odoe is equal to 3 (Student's t-test: $p=0.5$ ), attests that the growth is isometric (Table 1). In contrast, 26 species (93\%) have an allometry coefficient (b) significantly different from 3 (Student's t-test: $\mathrm{p}<$ 0.05). Among these species, 22 species show negative allometric growth ( $b<$ 3). These are Elops lacerta, Pellonula leonensis, Pellonula vorax, Ethmalosa fimbriata, Chrysichthys maurus, Chrysichthys nigrodigitatus, Schilbe mandibularis Hemichromis fasciatus, Sarotherodon melanotheron, Coptodon guineensis, Coptodon hybride, Coptodon zillii, Pelmatolapia mariae, Tylochromis jentinki, Pomadasys jubelini, Monodactylus sebae, Trachinotus teraia, Awaous lateristriga, Gobioides sagitta, Porogobius schlegelii, Citharichthys stampflii et Cynoglossus senegalensis. On the other hand, 4 species such as Labeo coubie, Neochelon falcipinnis, Parachanna obscura and Polydactylus quadrifilis have a positive allometric growth $(\mathrm{b}>3)$.

As for the condition factors $\mathrm{K}$, the results in Table 1, indicate that 27 fish species $(96.42 \%)$ out of the 28 have a good body weight. Only Schilbe mandibularis has a bad weight. The average condition factors vary from 0.935 \pm 0.966 for Schilbe mandibularis to $113.3 \pm 10.644$ for Chrysichthys maurus. 
ESJ Natural/Life/Medical Sciences

\begin{tabular}{|c|c|c|c|c|c|c|c|c|c|c|c|c|c|}
\hline \multirow[b]{2}{*}{ Family } & \multirow[b]{2}{*}{ Species } & \multirow[b]{2}{*}{$\mathrm{N}$} & \multicolumn{2}{|c|}{ Standard length } & \multicolumn{2}{|c|}{ Weight } & \multicolumn{7}{|c|}{ Length - Weight Relationship } \\
\hline & & & Min & Max & Min & Max & $\mathrm{a}$ & $\mathrm{b}$ & SE (b) & $r^{2}$ & Growth & $\mathrm{t}$ & $\mathrm{K}$ \\
\hline Elopidae & $\begin{array}{l}\text { Elops lacerta } \\
\text { Pellonula }\end{array}$ & 56 & 7,6 & 22 & 15 & 103 & 1,28 & 1,306 & 0,093 & 0,483 & A- & $-1,499$ & 1,685 \\
\hline \multirow[t]{3}{*}{ Clupeidae } & leonensis & 21 & 3,8 & 10,2 & 1 & 30 & 0,255 & 1,87 & 0,121 & 0,543 & A- & $-1,149$ & 6,874 \\
\hline & $\begin{array}{c}\text { Pellonula vorax } \\
\text { Ethmalosa }\end{array}$ & 10 & 2,5 & 8 & 1 & 19 & 1,307 & 1,117 & 0,107 & 0,307 & A- & $-1,302$ & 15,86 \\
\hline & fimbriata & 18 & 4,7 & 17,5 & 11 & 101 & 0,107 & 2,275 & 0,136 & 0,645 & A- & $-1,028$ & 4,063 \\
\hline Hepsetidae & $\begin{array}{c}\text { Hepsetus odoe } \\
\text { Distichodus }\end{array}$ & 33 & 12,3 & 22,5 & 30 & 356 & 0,012 & 3,036 & 0,142 & 0,883 & I & $-0,989$ & 1,624 \\
\hline Distichodontidae & rostratus & 52 & 9 & 20,5 & 13 & 198 & 0,018 & 3,023 & 0,114 & 0,891 & I & $-1,222$ & 1,98 \\
\hline Cyprinidae & $\begin{array}{l}\text { Labeo coubie } \\
\text { Chrysichthys }\end{array}$ & 11 & 12,7 & 22 & 49 & 295 & 0,001 & 4,272 & 0,152 & 0,936 & $\mathrm{~A}^{+}$ & $-0,917$ & 2,502 \\
\hline \multirow[t]{2}{*}{ Claroteidae } & $\begin{array}{c}\text { maurus } \\
\text { Chrysichthys }\end{array}$ & 69 & 14 & 33,5 & 44 & 312 & 36,103 & 0,413 & 0,147 & 0,115 & A- & 0,947 & 113,299 \\
\hline & $\begin{array}{l}\text { nigrodigitatus } \\
\text { Schilbe }\end{array}$ & 147 & 8,5 & 24 & 11 & 293 & 0,082 & 2,541 & 0,148 & 0,646 & A- & $-0,942$ & 2,309 \\
\hline Schilbeidae & $\begin{array}{l}\text { mandibularis } \\
\text { Hemichromis }\end{array}$ & 45 & 11,5 & 18,5 & 13 & 78 & 0,127 & 2,077 & 0,098 & 0,475 & A- & $-1,416$ & 0,935 \\
\hline \multirow[t]{6}{*}{ Cichlidae } & $\begin{array}{c}\text { fasciatus } \\
\text { Sarotherodon }\end{array}$ & 76 & 5,6 & 16,2 & 8 & 148 & 0,06 & 2,746 & 0,133 & 0,789 & A- & $-1,048$ & 3,262 \\
\hline & $\begin{array}{l}\text { melanotheron } \\
\text { Coptodon }\end{array}$ & 658 & 6,5 & 50 & 3 & 999 & 0,23 & 2,315 & 0,207 & 0,923 & A- & $-0,673$ & 3,773 \\
\hline & $\begin{array}{l}\text { guineensis } \\
\text { Coptodon }\end{array}$ & 23 & 9 & 16,1 & 35 & 152 & 0,09 & 2,391 & 0,143 & 0,553 & A- & $-0,979$ & 4,084 \\
\hline & hybride & 63 & 6,8 & 16,3 & 19 & 155 & 0,114 & 2,528 & 0,127 & 0,92 & A- & $-1,098$ & 3,472 \\
\hline & $\begin{array}{l}\text { Coptodon zillii } \\
\text { Pelmatolapia }\end{array}$ & 427 & 7,3 & 23,1 & 15 & 471 & 0,064 & 2,781 & 0,162 & 0,929 & A- & $-0,864$ & 3,663 \\
\hline & mariae & 20 & 9 & 15 & 35 & 148 & 0,046 & 2,663 & 0,148 & 0,577 & A- & $-0,943$ & 4,502 \\
\hline
\end{tabular}




\begin{tabular}{|c|c|c|c|c|c|c|c|c|c|c|c|c|c|}
\hline & $\begin{array}{c}\text { Tylochromis } \\
\text { jentinki } \\
\text { Pomadasys }\end{array}$ & 126 & 7,5 & 19,5 & 8 & 199 & 0,059 & 2,696 & 0,148 & 0,85 & A- & $-0,941$ & 2,78 \\
\hline Haemulidae & $\begin{array}{c}\text { jubelini } \\
\text { Monodactylus }\end{array}$ & 40 & 10,1 & 21 & 30 & 298 & 0,029 & 2,943 & 0,182 & 0,643 & A- & $-0,767$ & 3,172 \\
\hline Monodactylidae & $\begin{array}{c}\text { sebae } \\
\text { Polydactylus }\end{array}$ & 56 & 5,5 & 13 & 12 & 147 & 0,476 & 1,991 & 0,097 & 0,637 & A- & $-1,434$ & 5,453 \\
\hline Polynemidae & $\begin{array}{l}\text { quadrifilis } \\
\text { Trachinotus }\end{array}$ & 21 & 7,5 & 21 & 7 & 211 & 0,011 & 3,142 & 0,149 & 0,829 & $\mathrm{~A}+$ & $-0,936$ & 2,447 \\
\hline Carangidae & $\begin{array}{c}\text { teraia } \\
\text { Parachanna }\end{array}$ & 48 & 4,3 & 15 & 13 & 198 & 0,365 & 1,837 & 0,093 & 0,615 & A- & $-1,502$ & 3,351 \\
\hline Channidae & $\begin{array}{l}\text { obscura } \\
\text { Awaous }\end{array}$ & 32 & 13,7 & 32,5 & 61 & 807 & 0,005 & 3,381 & 0,217 & 0,878 & $\mathrm{~A}+$ & $-0,645$ & 2,187 \\
\hline \multirow[t]{3}{*}{ Gobiidae } & $\begin{array}{c}\text { lateristriga } \\
\text { Gobioides }\end{array}$ & 79 & 7,3 & 24 & 15 & 409 & 0,185 & 2,345 & 0,204 & 0,745 & A- & $-0,685$ & 3,014 \\
\hline & $\begin{array}{c}\text { sagitta } \\
\text { Porogobius }\end{array}$ & 38 & 5,6 & 31,2 & 13 & 90 & 0,873 & 1,473 & 0,086 & 0,502 & A- & $-1,625$ & 2,248 \\
\hline & & 13 & 6,5 & 10,1 & 9 & 26 & 0,046 & 2,575 & 0,133 & 0,782 & A- & $-1,045$ & 2,772 \\
\hline Mugilidae & $\begin{array}{l}\text { falcipinnis } \\
\text { Citharichthys }\end{array}$ & 17 & 10,7 & 27,5 & 36 & 1000 & 0,011 & 3,138 & 0,247 & 0,759 & $\mathrm{~A}+$ & $-0,565$ & 3,246 \\
\hline Paralichthyidae & $\begin{array}{c}\text { stampflii } \\
\text { Cynoglossus }\end{array}$ & 80 & 3,6 & 14,3 & 10 & 53 & 2,486 & 1,041 & 0,117 & 0,456 & A- & $-1,192$ & 3,557 \\
\hline Cynoglossidae & senegalensis & 15 & 8,7 & 22,5 & 25 & 157 & 0,022 & 2,845 & 0,136 & 0,766 & A- & $-1,023$ & 2,136 \\
\hline
\end{tabular}

Table I: Length-weight relationship, allometry coefficient, growth type and condition factor of 28 fish species caught in the mangroves of Azagny National Park between March 2019 and February 2020.

N: number; Min: minimum; Max: maximum; a and b: growth parameters; SE (b): standard error of b; $\mathrm{r}^{2}$ : coefficient of determination; A: allometry; I: Isometry 
ESJ Natural/Life/Medical Sciences

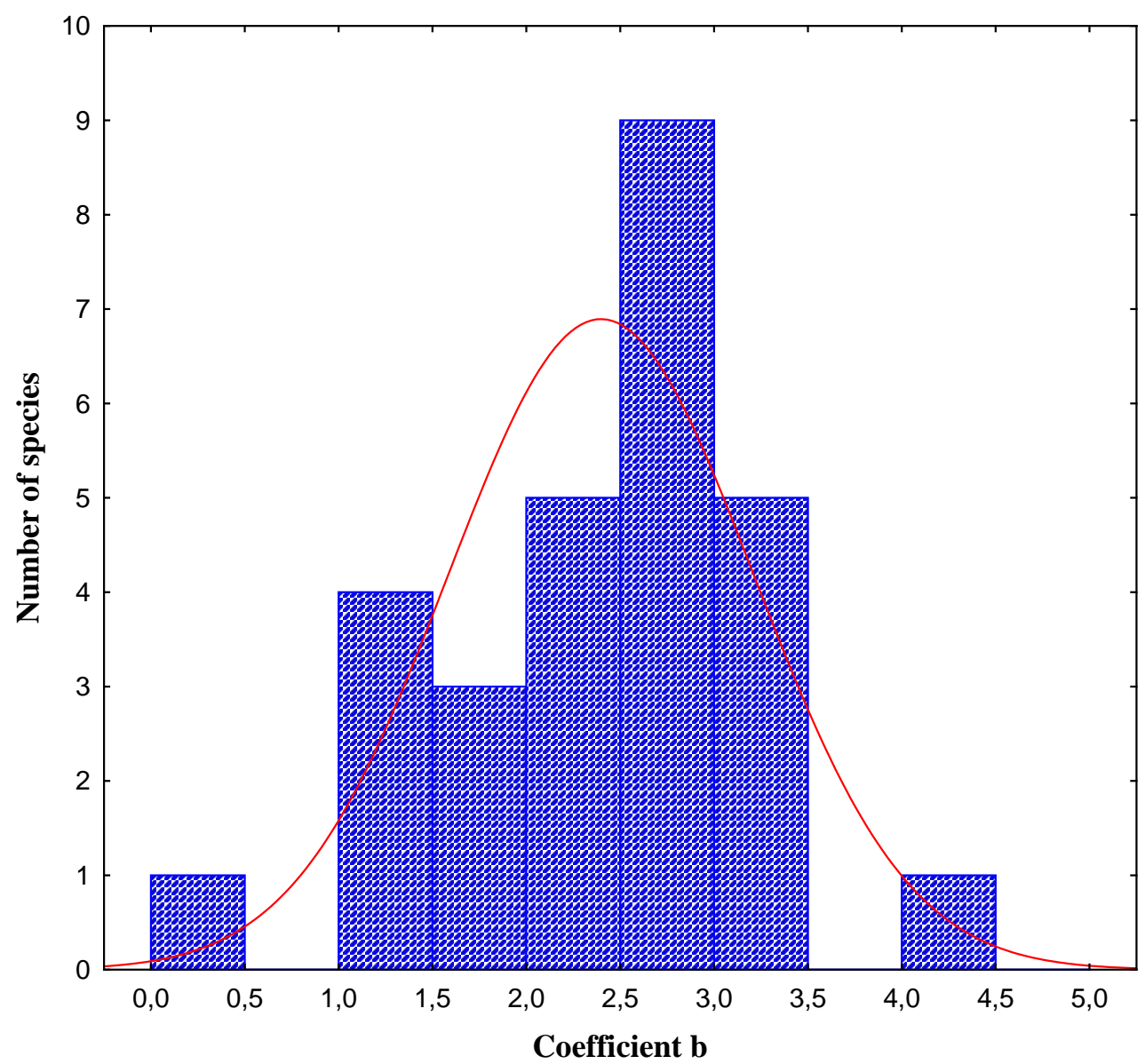

Figure 2: Distribution of b value for length-weight relationships in 28 fish species caught in ANP mangroves between March 2019 and February 2020.

\section{Discussion}

Allometry coefficients (b) ranged from 0.413 for Chrysichthys maurus to 4.272 for Labeo coubie with a mean of $2.384 \pm 0.810$. This mean value is significantly different from 3 (Student's t-test: $p<0.05$ ). This is in contrast to the results obtained by Mikembi et al. (2019) for 13 species and Dembe et al. (2020) for 16 fish species in Congo but does not differ from observations made in Ivory Coast for 15 fish species exploited in the Ebrié Lagoon (Nobah et al., 2019). In addition, the allometry coefficient is significantly less than 3 for most species (Table 1). The values of this coefficient for Distichodus rostratus (3.02) and for Hepsetus odoe (3.03) are not significantly different from 3 
(Student's t-test: $\mathrm{p}=0.05$ ), indicating isometric growth. In contrast, Labeo coubie, Neochelon falcipinnis, Parachanna obscura and Polydactylus quadrifilis have positive allometric growth resulting in a b coefficient greater than 3 (Student's t-test: $\mathrm{p}<0.05$ ). This indicates better growth in weight than in length of these species (Da et al., 2018). Indeed; fish with positive allometric growth, are heavier reflecting optimal growth conditions. However, this result is contrary to that of Koffi et al. (2014) who worked in the Aby Lagoon in Ivory Coast and Dembe et al. (2020) in the Mvassa Lagoon in Congo, who reported negative allometry for these fish. These changes in growth patterns can be justified by environmental parameters related to the changing hydrological regime. For twenty-two (22) species (Elops lacerta, Pellonula leonensis, Pellonula vorax, Ethmalosa fimbriata, Chrysichthys maurus, Chrysichthys nigrodigitatus, Schilbe mandibularis, Hemichromis fasciatus, Sarotherodon melanotheron, Coptodon guineensis, Coptodon hybride, Coptodon zillii, Pelmatolapia mariae, Tylochromis jentinki, Pomadasys jubelini, Monodactylus sebae, Trachinotus teraia, Awaous lateristriga, Gobioides sagitta, Porogobius schlegelii, Citharichthys stampflii and Cynoglossus senegalensis.), the value of $\mathrm{b}$ is less than 3 (Student's t-test: $\mathrm{p}<0.05$ ) and shows that the growth of these fishes is of negative allometric type characterized by a growth in length more important than the growth in weight. Similar results were observed by Kamelan et al. (2014) and N'Dri et al. (2020), in Taï National Park and Lake Buyo, respectively. On the other hand, this result is different from the work of Hazoume et al. (2017) in the Sô River in Benin where the value of the coefficient b indicates a positive allometry for most of the species in the said river.

The generally accepted norms for the allometry coefficient are between 2 and 4 (Bagenal and Tesch, 1978). Thus, except for a few samples, the various values observed in the present study are in accordance with those usually reported and accepted in the literature. The low values of the allometry coefficient $(b<2.5)$ observed in the ANP mangroves could be related to a narrow sample size range. According to Yakubu et al. (2016), the allometry coefficient is related to the quality of the aquatic environment. Indeed, mangroves undergo a galloping demographic pressure through domestic discharges and canalization with direct discharges into the environment impacting the growth of species. These mangroves are like nursery and spawning areas, sheltering an important proportion of fish resources and juvenile fish. Therefore, the low values of allometry coefficient can be associated with a food competition by the availability of resources in the environment. Thus, it can be inferred that the low values of allometry coefficient of fish in ANP could be due to the advanced state of degradation an anthropogenic activities, such as overfishing by local fishermen, removal of sand for construction and cutting of firewood and timber. Indeed, the study 
area is being an island, the riparian populations have only fished as their main activity, which could also justify the variation of the fish b coefficient. According to Biswas (1993), the variation of $b$ in different regions would be due to the physiological conditions of the fish, the time of collection, the sex, the development of the gonads and the nutritive conditions in the fish environment. This variation in allometry coefficient could also be justified by the destruction of food sources leading to their scarcity, thus constraining the ideal growth of fish.

The condition factor $(\mathrm{K})$ gives a good idea of the overweight of the fish, i.e. the relative importance of its body mass compared to its length. It is a parameter that allows us to compare species to each other or to the same species in different environments and to characterize the quality of the trophic relationship between the fish and its environment (Kumolu-Johnson and Ndimele, 2010). The condition factor (K) in the present study is generally greater than 1 , which would mean that fish are doing well in this ecosystem. According to Alhassan et al. (2015),

$\mathrm{K} \geq 1$ expresses that the fish are in good conditions and $\mathrm{K}<1$ means that the fish are not overweight in their biotope. On the other hand, the lowest condition factor was observed in Schilbe mandibularis (0.935) and the highest in Chrysichthys maurus (113.3). Twenty-seven (27) species of mangrove fish namely Elops lacerta, Pellonula leonensis, Pellonula vorax, Ethmalosa fimbriata, Hepsetus odoe, Distichodus rostratus, Labeo coubie, Chrysichthys maurus, Chrysichthys nigrodigitatus, , Hemichromis fasciatus, Sarotherodon melanotheron, Coptodon guineensis, Coptodon hybride, Coptodon zillii, Pelmatolapia mariae, Tylochromis jentinki, Pomadasys jubelini, Monodactylus sebae, Polydactylus quadrifilis, Trachinotus teraia, Parachanna obscura, Awaous lateristriga, Gobioides sagitta, Porogobius schlegelii, Neochelon falcipinnis, Citharichthys stampflii as well as Cynoglossus senegalensis had their K-values outside the range (2.4 - 4.8) recommended as appropriate for mature freshwater fish by Bagenal and Tesch (1978). The condition factor values obtained in the present study show that the species studied were in good conditions in the PNA mangroves. This was not the case in Schilbe mandibularis. These results are similar to those found in the twenty-four fish species where $\mathrm{K}$ values are greater than 1 , except in Mormyrus rume (0.79) in Lake Buyo (N'Dri et al., 2020). This difference would be related to species, sex and diet. On the other hand, Konan et al. (2014) showed that the high values of condition factor K could be explained by the presence of a diverse and abundant diet in the environment.

\section{Conclusion}

The present study, which provides information on the length-weight relationships and condition factors of 28 fish species, provides information on 
the biology of the fish fauna of the mangroves of the ANP. It mainly provides an important database for researchers and nature managers in the development of management and conservation measures for mangrove fish populations. Indeed, the knowledge of the length-weight relationship and the condition factor of the species targeted by this study, because it allows to put at the disposal of the decision-makers, data likely to help in the elaboration of measures of optimal and sustainable management of the mangrove ecosystems of the ANP. In the Azagny mangroves, the present study noted 2 species of fish showing isometric growth, 4 species showing positive allometry and 22 species showing negative allometry. Most of the species studied have et good weight. The mangroves, because of their richness in biodiversity are widely exploited by man. However, in the face of the galloping demographic growth of the populations of the Azagny area, these ecosystems are increasingly threatened and / or overexploited. It is therefore necessary to draw the attention of the populations to the importance of these areas and the aquatic organisms that live there for the sustainability of aquatic biodiversity.

This work was carried out within the framework of the Strategic Support Program for Scientific Research (PASRES) doctoral research project $\mathrm{N}^{\circ} 199$ entitled "Conservation status of aquatic biodiversity in Azagny National Park (Ivory Coast)". This project was financed by the PASRES. The authors would like to thank all the people who participated in the collection of data in the field and the researchers who contributed significantly to the work.

\section{References:}

1. Avenard J.M., Eldin M., Girard G., Sircoulon J., Touchebeuf P., Guillaumet J.L., Adjanohoun E. \& Perraud A. (1971). (eds). Le Milieu Naturel de Côte d'Ivoire, Mémoire ORSTOM, France, pp 7- 70.

2. Alhassan E H., Akongyuure D N. \& Asumang F. (2015). Determination of Morphometric Relationship and Condition Factors of Four Cichlids from Golinga Reservoir in Northern Region of Ghana. Online Journal of Biological Science, 15(3): 201-206.

3. Barbier E.B., Hacker S.D., Kennedy C., Koch E.W., Stier A. \& Sillliman B.R. (2011). The value of estuarine and coastal ecosystem services. Ecological Monographs 81(2): 169-193.

4. Baby F., Tharian J., Abraham K M., Ramprasanth M R., Ali A. \& Ranghavan R. (2011). Length-weight relationship and condition factor of an endemic stone sucker, Garra gotyla Stenorbynchus (Jerdon, 1849) from two opposite flowing rivers in southern Western Ghats. Journal of threatened taxa 3(6): 1851-1855.

5. Bagenal T.B. (1978). Age and growth (chapter 5). In: Methods for assessments of fish 
production in fresh water (Bagenal T., ed), IBP Handbook. Blackwell Scientific Publication, Oxford: 101-136.

6. Batiabo M.A.L, Ibala Z.A., Mamonekene V., Dembe L.T.H., Poaty N.F.H. \& Vouidibio J. (2019). Relations longueurs-poids et coefficients de condition pour 13 espèces de poissons de la rivière Dzoumouna, affluent du cours inferieur du fleuve Congo (République du Congo). Journal of Animal and Plant Sciences 39(1): 6384-6393.

7. Biswas S.P.L. (1993). Manual of methods in fish biology South Asian Publisher. 60-63

8. Bolognini L., Domenichetti F., Grati F., Polidori P., Scarcella G. \& Fabi G. (2013). Weight-Length Relationships for 20 Fish Species in the Adriatic Sea. Turkish Journal of Fisheries and Aquatic Sciences, 13: 555-560.

9. Bouichou A. (1978). Etude géographique de la réserve d'Azagny et son environnement anthropique. Mémoire de Maîtrise, Université de Paris VIII .79 p.

10. Da Costa S. \& Araàjo, F.G. (2003). Length-weight relationship and condition factor of Micropogonias furnieri (Desmarest) (Perciformes, Sciaenidae) in the Sepetiba Bay, Rio de Janeiro State, Brazil. Revista Brasileira de Zoologia, 20 (4): 685-690

11. Da N., Ouédraogo R. \& Ouéda A. (2018). Weight-length relationship and condition factor for Clarias anguillaris and Sarotherodon galilaeus fished in Lake Bam and the Kompienga reservoir in Burkina Faso. International Journal of Biological and Chemical Sciences, 12: 1601-1610.

12. Dembe L.T.H., Ibala Z.A., Goma-Tchimbakala J., Batiabo M.L., Poaty N.H.F. \& Mamonekene V. (2020). Effets saisonniers sur les relations poids-longueurs et coefficients de condition pour 16 espèces de poissons de la Lagune Mvassa, basse Guinée, République du Congo. Journal of Animal and Plant Sciences, 44(1): 7

13. Duarte C.M., Agusti S., Barbier E.B., Britten G.L., Castilla J.C., Gattuso J-P., Fulweiler R.W., Hughes T.P., Knowlton N., Lovelock C.E., Lotze H.K., Predragovic M., Poloczanska E., Roberts C. \& Worm B. (2020). Rebuilding marine life. Nature, 580: 39-51.

14. Égnankou W. M. (2009). Réhabilitation des mangroves comprises entre Fresco et Grand Lahou en Côte d'Ivoire : Zones importantes pour la pêche, In : "L'importance des forêts de mangrove pour la pêche, la faune sauvage et les ressources en eau en Afrique », Nature et faune, FAO, 24 (1) : 85-93.

15. Gilman E.L., Ellison J., Duke N.C. \& Field C. (2008). Threats to mangroves from climate change and adaptation options: a review. Aquatic botany, vol. 89, pp 237-250. 
16. Giri C., Ochieng E., Tieszen L.L., Zhu Z., Singh A., Loveland T., Masek J. \& N. Duke. (2011). Status and distribution of mangrove forests of the world using earth observation satellite data. Global Ecology and Biogeography. 20: 154 -159.

17. Hazoume RUS., Chikou A., Koudenoukpo C., Adite A., Bonou C A. \& Mensah G A. (2017). Length-weight relationships of 30 species of fish of the river Sô in Benin (West Africa). International Journal of Fisheries and Aquaculture Studies, 5(3): 514-519.

18. Hossain M Y., Mosaddequr R M d., Fulanda B., Jewel M A S., Ahamed F. \& Ohtomi J. (2012). Length-weight and length-length relationships of five threatened fish 196 species from the Jamuna (Brahmaputra River tributary) River, northern Bangladesh. Journal of Applied Ichthyology 28: 275-277

19. Ibala Z.A., Vreven E., Mamonekene V., Musschoot T., Poaty Ngot H.F. \& Snoek J. (2020). Length-weight relationships of 37 freshwater fish species from the Lefini River, middle Congo River basin (Republic of the Congo). Journal of Applied Ichthyology 00: 1-6.

20. Lalèyè P A. (2006). Length-weight and length-length relationships of fishes from the Ouémé River in Bénin (West Africa). Journal of Applied Ichthyology 22 (4): 330-333.

21. Le Cren E D. (1951). The length-weight relationship and seasonal cycle in gonadal weight and condition in the perch (Perca fluviatilis). Journal of Animal Ecology 20: 201-219.

22. Lévêque C, Paugy D \& Teugels G G. (1990). Faune des poissons d'eaux douces et saumâtres de l'Afrique de l'Ouest. Volume 1, MRAC (Tervuren), ORSTOM (Paris), collection faune tropicale, 28: 384 pp.

23. Kamelan T.M., Berté S., Bamba M., Yao S.S., N’Zi K.G. \& Kouamélan E.P. (2014). Spatio-temporal patterns of fish assemblages and influential environmental gradients in a West African basin (Tai National Park, Côte d'Ivoire). Eur. J. Sci. Res, 121 (2): 145-160.

24. Koffi K.B., Berté S. \& Koné T. (2014). Length-weight Relationships of 30 Fish Species in Aby Lagoon, Southeastern Côte d'Ivoire, Current Research Journal of Biological Sciences 6 (4): 173-178.

25. Kumolu-Johnson C.A. \& Ndimele P.E. (2010). Length-Weight Relationships and Condition Factors of Twenty-One Fish Species in Ologe Lagoon, Lagos, Nigeria. Asian Journal of Agricultural Sciences, 2(4): 174-179.

26. Mikembi A., Mamonekene V., Tenda H, Ngot F. \& Vouidibio J. (2019). Relations longueurs-poids et coefficients de condition pour 13 espèces de poissons de la rivière Dzoumouna, affluent du cours inférieur du fleuve Congo (République du Congo). Journal of Animal and Plant Sciences, 39 (1), 6384-6393. 
27. N’Dri O.R., Konan Y.A., Bamba M., Monney A. I. \& Koné T. (2020). Length-weight relationships and condition factor of twenty-four freshwater fish species from lake Buyo, Côte D'Ivoire. Journal of Fisheries and Aquatic Sciences, 15: 27-34.

28. Paugy D., Lévêque C. \& Teugels G.G. (2003a). Faune des Poissons d'eaux douces et saumâtres de l'Afrique de l'Ouest, volume 1. Collection faune tropicale 40. Institut de Recherche pour le Développement (IRD) (Paris, France) MRAC et MHN 457 p.

29. Paugy D., Lévêque C. \& Teugels G. G. (2003b). Faune des Poissons d'eaux douces et saumâtres de l'Afrique de l'Ouest, volume 2. Collection faune tropicale 40. Institut de Recherche pour le Développement (IRD) (Paris, France) MRAC et MHN 815 p.

30. UNEP. (2014). The importance of mangroves to people: a call to action. Van Bochove J., Sullivan E., Nakamura T. [Eds.]). United Nations Environment Program World Conservation Monitoring Centre, Cambridge, $128 \mathrm{pp}$.

31. Yakubu Y.I., Oluranti B N., Ewutanure J. \& Rilwan U. (2016). Food Habit and Growth Pattern of Oreochromis niloticus in Wase Dam, Nigeria. Nature and Science, 14(12): 46-49. DOI: http://dx.doi.org /10.1007/s11160-009-9152-z

32. Youmbi T.J., Djama T. \& Gabche C.E. (1991). Reproductive patterns of Sardinella maderensis with emphasis on Cameroon Fish byte, 7 (3):13. 